In 1917 and 1918, Charles Hubert Farnsworth, a leading music educator from Teachers College, Columbia University, and David Snedden, a critic and educational theorist of national repute, privately exchanged views on the role of art and music in society and in education. Snedden mulled over Herbert Spencer's query "What knowledge is of most worth?" and concluded that music must have practical survival value: it must contribute primarily to the maintenance of social and political order and secondarily to other aims. Farnsworth, on the other hand, thought that music performance or appreciation should be for the immediate joy that it gives the individual, not for some deferred social purpose no matter how important it might be. These divergent positions are explained in light of Farnsworth's interests in philosophy and Snedden's schooling in Spencerian and Darwinian thought.

William R. Lee, Visiting scholar, University of Michigan, Ann Arbor

\title{
The Snedden-Farnsworth Exchanges of 1917 and 1918 on the Value of Music and Art in Education
}

\section{BACKGROUND}

In 1917, Charles Hubert Farnsworth, a professor of music education, sent a printed copy of an essay outlining his ideas on how music educates to each of his colleagues at Teachers College, Columbia University. David Snedden, also a professor at Teachers College, disagreed strongly with what Farnsworth had written. Between July 18, 1917, and March 5,

The author wishes to thank Allen P. Britton, University of Michigan, for his helpful suggestions during the writing of this paper and Hubert P. Henderson, University of Kentucky, who oversaw the preparation of some of this material for inclusion in the author's dissertation. Travel grants, provided by the Graduate School of the University of Kentucky and Georgetown College, contributed to the gathering of material.

For reprints of this article, contact William R. Lee, 314 East Lincoln Avenue, Ada, Ohio 45810 . 

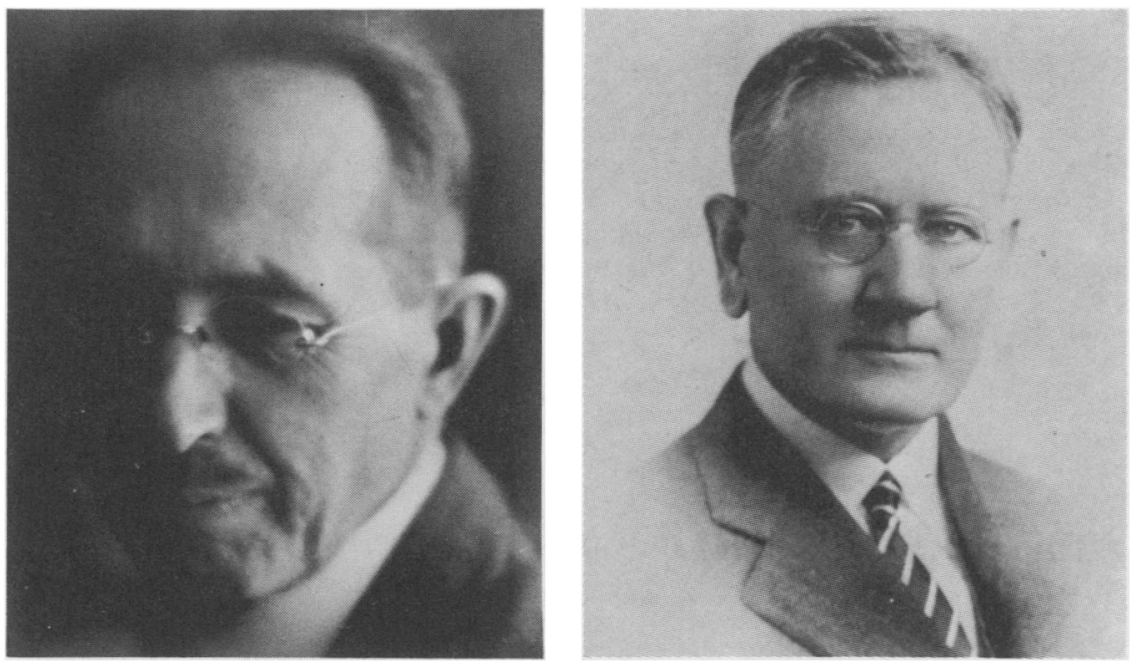

Note. Charles Hubert Farnsworth, 1859-1947, (left). Photograph circa 1920 courtesy of Teachers College, Columbia University, New York. Reprinted by permission. David Snedden, 1868-1951, (right). Teachers College, Columbia University, New York. Photograph from David Snedden and Education for Social Efficiency by W. H. Drost, 1967, Madison: University of Wisconsin Press. Copyright 1967 from the University of Wisconsin Press. Reprinted by permission.

1918, Snedden and Farnsworth exchanged a series of notes amounting to more than two dozen single-spaced, typewritten pages outlining their divergent positions on the value of art and music in society and in education (Farnsworth, unpublished papers, 1886-1947).

Both Farnsworth and Snedden were members of the faculty of Teachers College at a time when many pioneers in education held positions there, including John Dewey, E. L. Thorndike, Frank M. McMurry, and William H. Kilpatrick. Snedden (1868-1951) was a critic and educational theorist of national repute. He was a former Stanford University professor, former commissioner for education in Massachusetts, founder of vocational education and educational sociology, and a powerful and often controversial figure (Drost, 1967, p. 3). Farnsworth (1859-1947) had gained wide recognition in music teaching circles for his ideas on the goals and purposes of music in education and was popular and influential in the Music Teachers National Association and the Music Supervisors National Conference, later called the Music Educators National Conference (Lee, 1982, pp. 1-3). A quiet, courtly, middle-class gentleman, he was known as "our philosopher" among his many admirers (Gehrkens, 1937, p. 24).

Farnsworth's and Snedden's ideas were formulated amid many changes taking place in education. The first two decades of the 20th century saw a period of intense growth in American schools. Thousands 
of teachers were trained, and buildings were erected to accommodate a growing population and an influx of new immigrants. Curricula were planned, educational theories proffered and debated, and schools of education established in the great universities. Personalities appeared in education who attracted international attention, including Dewey, Thorndike, and Kilpatrick (Commager, 1976, p. 29).

Music teaching in the public and private schools was very much a part of this ferment, producing its own personalities, organizations, and educational dogmas. The purposes and goals of school music were much debated (Birge, 1937, p. 126), especially in the decade of 1910 when powerful forces in business and industry began to influence changes in the U.S. school curricula (Callahan, 1962, p. 124).

"Efficiency" became the chief watchword of the decade among school administrators and was understood to mean both an efficient use of school materials and time and an efficient use of one's life in schooling (Drost, pp. 135-136; Seashore, 1913, p. 224). The Music Supervisors National Conference chose "efficiency" as the theme for its 1914 convention. Standards of musical accomplishment were discussed so that music learning might eventually be efficiently gauged by surveying and testing (Birge, 1937, p. 218).

Other pressures were being felt. The classical tradition in education in the United States was in sharp decline, and there was agitation to include vocational and practical courses in curricula. The merits of various school subjects and the amount of time they should be given were often heatedly debated (Callahan, pp. 46-52).

Controversial exchanges, usually more in the public eye, were not unusual for Snedden. Late in the decade of 1910, he was regarded by many as a symbol of irresponsible educational reform and attracted considerable attention among school administrators and the public with his ideas. In 1914 and 1915, he had a famous series of exchanges with Dewey in the New Republic on educational policy. In 1917, he began attacking the beliefs of subject area specialists in Latin, history, physics, and art in his speeches and published writings (Drost, pp. 3, 6, 131, 145, 147-149).

Snedden based his attacks on considerable study. From sociological studies and from reading the works of economist Edward A. Ross, Herbert Spencer, and others, he concluded that school subjects must, above all, have survival value-that is, they must have a direct and obvious influence on the student's future ability to live and work efficiently in society, or they must contribute substantially to the social control of the population. Pursuing study simply for pleasure was strongly rejected (Drost, pp. 3-4, 43, 114-115).

A synthesis of these and other ideas are what Snedden called "education for social efficiency," and he hoped for the day when they could be based on scientific principles. Snedden's notions, strongly political and social, influenced curricula reform and the development of vocational training during this period (Drost, pp. 3, 27, 47, 188-189, 191).

Farnsworth, on the other hand, saw danger in the methods and goals of Snedden. In the manner of old-line pedagogists such as his friend 
Frank M. McMurry, a former leader of the Herbart Society, he sought to construct a set of first principles in the pedagogy of teaching from which a methodology could be derived. To do this, he looked for answers in philosophy, the psychologically oriented, hedonistic aesthetics of the time, and to some extent in the dogma of G. Stanley Hall's Child Study Movement (Lee, p. 157, chap. 8).

\section{THE EXCHANGES}

In a three-page note sent to Farnsworth on July 18, 1917, Snedden attacked Farnsworth's justification of music in the school curriculum based on many of these ideas, particularly Farnsworth's use of the concept of aesthetic pleasure as a central principle. Snedden was unable to see a difference between aesthetic pleasure and any other kind of pleasure. Arguing that aesthetic pleasures have always been developed fundamentally for useful purposes, he asserted that pleasure alone was a totally insufficient justification for music instruction:

I find especial difficulty in your contention that "what gives worth to music is the pleasure it awakens." It seems to me that all profound studies of philosophy, psychology, and biology point to the general conclusion that both pleasure and pain in all functions of life must be regarded as forms of stimuli (in reality, as means and not as ends). It is true that, at any given moment, the individual tends to make pleasure his end, but when this is done over a long period of time or by large numbers of people in common, it seems to me historically true that it leads to all those forms of degeneration which come from short-circuiting the processes of life or confusing means with ends. The capacity to receive pleasure in any situation, as well as the capacity to take pain from other situations, have been evolved through long ages as means of securing the maximum of useful [human] functioning. (Snedden to Farnsworth, July 18, 1917)

Snedden enclosed with his criticism "The Waning Power of Art," an article that he had published in May 1917, in which he argued that with the rise of science and modern thinking, art-under which he subsumed music-no longer possessed survival value, and it might no longer be justifiable to place it in the school curriculum (Snedden, 1917, pp. 805$809,819)$. In July 1917 , Snedden said to Farnsworth that in the past art had been vital and useful as a social function or some other purpose "that made for strength, wholeness, and unity of society." The world, he thought, had evolved past the stage where art could render great service to mankind in this respect.

Such arguments were at heart social and utilitarian (Dewey, 1915, p. 43). For Snedden, the chief value of all cultural subjects-which in his definition included painting, sculpture, literature, and music-was their use in social control. He defined social control as ways "men are held to their duties toward others" (Drost, p. 29). Snedden was indebted to the economist Ross, a former teacher at Stanford University, for many of his social ideas (Drost, p. 193), though others in education, including Dewey and Jane Addams, had similar concerns, recognizing the need to 
accommodate people to their work and social structure-despite the coercive implications (Katz, 1971, p. 119).

Snedden had spent most of his career mulling over Spencer's famous query "What knowledge is of most worth?" and injecting his conclusions into debates on curriculum reform. Ultimately, as has been shown, he came to believe that art should have practical use, especially practical social use. This valuation of art was in keeping with Spencer's ideas that different kinds of knowledge have different worths. Spencer had organized knowledge into five categories from most to least important: (1) knowledge that serves self-preservation, (2) activities that indirectly minister to self-preservation, (3) knowledge on the rearing of offspring, (4) knowledge that aids the maintenance of social and political order, and (5) knowledge that contributes to leisure activities. Snedden saw art as contributing to the last two categories (Drost, p. 20).

The result was that there were few areas of agreement between Farnsworth and Snedden. In his September 17, 1917, reply, Farnsworth questioned Snedden's valuing of art solely for its extrinsic worth:

If I understand your argument, it is that when we compare the use of art among primitive and less developed with the use of art among the most civilized of the present time, we find that art is holding a relatively less important position now than it did in the past. From this you infer that the power of art is waning. I am willing to admit that modern people do not make as general a use of art in their personal affairs, for instance, in fighting, love making, and religion as do primitive people. At the same time I do not agree with you in your inference that the power of art is waning. This difference from your conclusions is due to two reasons.

First your estimate of the worth of art is based almost entirely on its exchange value, for instance at the present time for its recreative and refining use. Thus it seems to me that you are measuring art by standards which only indirectly apply.

My second argument is that the change in the position of art in social life can be counted for in the process of evolution, and that we do not need to infer waning power. Instead I claim that there is going on a more specific and truer use of art.

Farnsworth vehemently argued for art "for its own sake," not for some practical purpose. The primary weakness of Snedden's argument, he pointed out, was his valuing of school subjects only for their deferred values, values to be realized at some point in the future. Farnsworth believed that the present, too, was important and that art values the present:

The stoic looks on the present as a preparation for tomorrow, he judges its worth by the values for which he can exchange it. Self restraint, discipline, all the joy that comes to him from a consciousness of a command over himself are for the anticipated worth of his conduct what he is to be. The epicurean looks on the present as having value in itself, and not for what it will do to make him better. To him it is really the fulfillment of past yesterdays. He, so to speak, cashes in his experience by the satisfaction that he takes out of it. 
It seems to me that these two forms of values should exist side by side and that the overemphasis of either one leads to a warped mental and emotional life. (Farnsworth to Snedden, September 17, 1917)

A realization of the importance of the present, Farnsworth believed, resembled some of the tenets of Christian theology when it emphasized the eternal now (Farnsworth to Snedden, September 17, 1917). The quality of "immediacy" in art, the characteristics of works of art to be valued directly and immediately in the present, was a chief theme in Farnsworth's work (Lee, pp. 142-143), and an important topic in the aesthetic thought of the late 19th and early 20th centuries (Bernstein, 1966, chap. 7).

Farnsworth rejected Snedden's use of art for social purposes:

This process of limiting art to its specific purpose in social life would naturally lead to a reduction of its mass influence, for art is primarily spiritual and to value it in its true worth means a state of society that we have not by any means reached at present. Only in unusual and sporadic cases like that of the Greeks was this true estimate of beauty, generally defused. It would be peculiarly characteristic of an age like ours, in which the practical and scientific advances of civilization are marked, to be deficient in the power of estimating the worth of the beautiful, but it seems to me that this is but a stage in the upward progress of society; that the pendulum will swing in the opposite direction, or perhaps, better, we shall turn our direction as we climb upwards on the spiral, and it will be found that our present epoch did not represent a normal valuation of the worth of art and could not be taken as indicating the waning power of what seems to be the most truly spiritual expression of human life. (Farnsworth to Snedden, September 5, 1917)

A mystical, transcendental outlook was characteristic of Farnsworth's thinking about music. Thus, when he wrote an article for the 1914 inaugural issue of the Musical Quarterly, he emphasized not only the immediacy of art but also the importance of its inward values (Farnsworth, 1915, pp. 162-168). Such ideas had earned Farnsworth the title of "our philosopher" and the "sage of Thetford" among his MSNC and MTNA colleagues (Gehrkens, 1937, p. 24).

For Snedden, education was means to an end and not an end in itself. Mystical or philosophical ideas had no place in his outlook (Drost, p. 171). In his reply on October 16,1917 , he reiterated his belief that real and ultimate survival values were the only ones worth considering for most people:

To the biologist (and psychologist and sociologist as well, so far as I know) these powers and capacities (powers to execute, capacities to receive, feel, appreciate) have taken shape, intensity, character, because for long periods in the evolution of the race they had a large "survival value."

Snedden and Farnsworth framed their arguments in variants of the evolutionary theories of Darwin that were popular in American thought at this time (Commager, 1950, chap. 4). For Farnsworth, Darwinian 
thought and its implications had contributed to his inner conflicts and had spurred his interest in philosophical thought (Farnsworth to Helen King, April 6, 1935). Snedden had studied evolutionary theory as an undergraduate (Drost, p. 13) and had ample opportunity for further contact with ideas through Spencer's works.

Snedden based his argument for present survival values partially on the belief that primitive man, and later modern man, was not really appreciative of deferred values:

The world loves the epicurean because in a sense he is what we would all be if we dared-the old Adam in us, primitive man whispering in our ears-but by the reflective, the informed, the experienced, the epicurean is viewed with suspicion, even as a source of dangerous contagion. The stoic feels, or rather realizes intellectually, that he must yield present to future satisfactions, personal to corporate pleasure, the here and now to the hereafter. Of course, we all recognize the type that becomes obsessed in this waycertainly no lovable type; but after all, the normal stoic is in all of us living under modern conditions—else we wouldn't be here!

\section{He goes on to suggest the following:}

It is also possible that my philosophy is essentially pragmatic, altho [sic] I have never wanted to describe myself as a pragmatist. But what you call the "practical functions of art" appear to me as being, in the larger social sense, the only functions that are worth considering, and in the course of evolution man's capacity for response to art developed only as society could get real and ultimate values for it-many of which, of course, are not exchangeable in any sense used by the economist. It seems to me, therefore, that if we could correctly analyze and appraise social values we should find that, as respects collective needs and enduring worths, art almost never has "value for its own sake." What for the moment seems to one of us such value merely represents the satisfaction of ancestral instincts which developed in their intensity when they served useful purposes. (Snedden to Farnsworth, October 16, 1917)

Were the goals of school music clear enough to justify the expense of music instruction? During the same discussion, Snedden had doubts:

In many quarters we are trying to develop the teaching of music. We begin now to appreciate our need of expert service, sustained effort, well organized curricula, and carefully tested methods, if we are to accomplish substantial results. All of these things will cost the public much money, and the children much time and effort which could be given to learning other things, acquiring other powers. What is the purpose of it all? Can we make ourselves a better people, more patriotic, more justice-loving, more kindly, more cultivated, more healthful, more spiritual by means of more and better music, among other things? We spend much of our resources on music now-certainly giving our exchangeable goods for it, such as it is. If diversion, individual satisfaction, mild recreation, are the chief possible results, why strive in public school education to raise the standards, to train powers of execution, to refine capacities for appreciation? 
How could music be made more socially efficient? In the same communication, Snedden said:

Now unless we can thus link up art with larger social purposes of the age in which we live-and I do not contend that we can do it consciously at all stages (much of past accomplishments in this direction was only vaguely conscious even to leaders), I fear it will go hard with music and other forms of art appeal in our school systems during the next generation, when the multiplying possibilities of education will force us to use the few thousand hours of the school life of the child for those purposes that count most in his development towards individual and social well-being.

It may indeed be, as I suggested in my published paper, that art can no longer serve our social ends-that henceforth we must use it in our leisure hours as a pastime, a diversion, a kind of refined indulgence.

In the years that followed, Snedden continued to criticize music education's "faith" objectives, yet he was positive about the role music could play and thought that music ought to have its fair share of time in curricula. He continued to believe that music, though probably not the other arts, could contribute to useful survival values if properly linked to them:

But nothing is more certain than that music-of certain kinds and used under special circumstances-when used as a means, can evoke appreciation of deferred values, as can few other forms of arts. It can induce man to yield the immediate satisfaction in living to the remoter satisfactions in the country's good. It can effect the substitution of higher sentiments, appreciation of subtler and relatively deferred values in a thousand directions. But to do this, it must be selected, dedicated, given precedence, linked up with ideals, associated with avowedly worthy objects. (Snedden, 1927, p. 342)

In 1931, he wrote that he hoped that vocal and instrumental opportunities and music appreciation could be offered to all children, but he still viewed music primarily as a useful socializing agent (Snedden, 1931, pp. 269-270,343). In a 1923 speech before MSNC in Cleveland, Ohio, he encouraged music educators to research carefully the social uses of music if they wished to understand their work better (Snedden, 1923, p. 51).

Music had always played a role in Snedden's conception of the ideal society. In his utopian "Gopher Prarie, A.D. 2000"-written as an optimistic answer to Sinclair Lewis's Main Street (1920)-he described an ideal community of the future and how education would have helped build it. Music, as one of the cultural utilities, would have contributed to social cohesiveness through the efforts of a small group of amateur performers and composers and a larger group of appreciators. Intense musical interests among the citizenry would transcend class and occupation. The development of this ideal would have relied on early identification of interest or ability among the young coupled with strong individual instruction (Snedden, 1923b, pp. 214-216).

Farnsworth held different views about the uses of music. He cited primitive man's use of magic and religious beliefs to ward off fears of the future as an example of primitive man's concern with the future as well 
as with the present. In talking with Snedden after 1917, Farnsworth believed that music could contribute to Snedden's social aims, but its primary purpose in the school cirriculum should be an immediate aesthetic one:

I am not denying that there is great practical social value in art. I wish merely to insist that the immediate motive in artistic production or appreciation is for the joy it gives, for its own sake, and not for these larger and more indirect values, however important they may be socially. (Farnsworth to Snedden, undated, after 1917)

And finally:

Immediate values are just as noble and worthwhile as deferred, requiring as much intelligence and courage for their realization. (Farnsworth to Snedden, September 17, 1917)

Farnsworth's mystical attitude was rooted in his 19th-century past. He was a product of New England culture. The son of New England missionaries stationed in Turkey, his education consisted of little more than a few months in the preparatory department of Robert College in Constantinople in the 1870s. Yet he acquired, through personal study and tutoring, a considerable command of philosophy and music. He was a Congregationalist, a relation and correspondent of important leaders in the liberal Protestant movement at the turn of the century (Lee, chaps. 2-3), and a member of the organization that was the focus of liberal Protestant efforts in education-the Religious Education Association. Like members of the REA, he tended toward intuitional theories of knowledge, regarded German philosophical thought as a reliable guide, and was intensely concerned with issues of inward value (Ahlstrom, 1972, pp. 781-784). For Farnsworth and these liberals, freedom and purpose had been crowded out of life by a society that too often emphasized materialistic and scientific values (Ahlstom, pp. 780-781; Cauthen, 1962, pp. 214, 216). Their concerns became his concerns applied in the teaching of music. His philosophical article in the first issue of the Musical Quarterly reflects many of their themes (Farnsworth, 1915, 162-168).

Farnsworth was also influenced by the rise of philosophical thought as a field of separate study in higher education in the 1890s (Lee, pp. 144146). German idealism, especially, served as a form of lay spirituality and a foil for business and scientific thinking among many educated people during this time (A history of the faculty of philosophy of Columbia University, 1957, p. 114). Influences on Farnsworth included, among others, aestheticians Walter Pater, Ethel Puffer, Vernon Lee, Henry Rutgers Marshall, Benard Bosanquet, and especially George L. Raymond (Lee, pp. 127-128).

Farnsworth and Snedden likely ended their written exchanges in early 1918. Neither man retreated from his original position to any real extent. Like Farnsworth, it was Snedden's habit when criticized or forced to defend a position simply to offer to explain his ideas in greater detail 
(Drost, p. 6). Both men brought to their argument ideas that had been formed over years of teaching, studying, and speaking. They probably remained on friendly terms, and it is likely that Snedden's speaking at the MSNC national meeting in 1923, paired on the program with Farnsworth (Program, 1923, p. 14), was Farnsworth's idea.

\section{EPILOGUE}

Over a decade later, Snedden retired to his ranch in California. He continued to be a prolific and controversial writer on educational matters, advocating, during the height of U.S. economic problems during the world wars, eugenics and collectivist economic ideas (Snedden, 1934, pp. 676, 682). Many of Snedden's ideas, often coercive and undemocratic from today's perspective, can be viewed as a response to the economic, social, and political upheavals of the World War I period and its aftermath.

Farnsworth retired to his lodge in rural Vermont in 1924 and continued his philosophical interests. For a time in the early 1930s, he practiced a type of daily meditation that resembled the routine of his neighbor Dright Goddard, a Bhuddist scholar and convert of Zen Bhuddism (Lee, p. 154). He worked for the National Broadcasting Company writing educational materials for Walter Damrosch's "Music Appreciation Hour" in the 1930s and published several books and papers, including his 1930 Short Studies in Musical Psychology (Birge, 1933, pp. 8-9). In his later years, he greatly influenced the outlooks of Karl Gehrkens and the psychologist-philosopher Max Schoen. He died in 1947 largely forgotten by his profession (Lee, pp. 199-200).

\section{REFERENCES}

Ahlstrom, S. (1972). A religious history of the American people. New Haven, CT: Yale University Press.

Bernstein, R. J. (1966). John Dewey. New York: Washington Square Press.

Birge, E. B. (May 1933). Supervisor sketches. The Musician, pp. 8-9.

Callahan, R. E. (1962). Education and the cult of efficiency. Chicago: University of Chicago Press.

Cauthen, K. (1962). The impact of American religious liberalism. New York: Harper and Rowe.

Commager, H. S. (1950). American mind, an interpretation of American thought since the 1880s. New Haven, CT: Yale University Press.

Commager, H. S. (1976). The people and their schools. Bloomington, IN: Phi Delta Kappa Educational Foundation.

Dewey, J. (1915, May). Education v. trades training-Dr. Dewey's reply. New Republic, pp. 42-43.

Drost, W. H. (1967). David Snedden and education for social efficiency. Madison, WI: University of Wisconsin Press.

Farnsworth, C. H. (1915, January). The judgment of Paris or the worth of beauty. Musical Quarterly, pp. 162-168.

Farnsworth, C. H. Unpublished papers, circa 1886-1947. Thetford Historical Society, Thetford, VT. 
Gehrkens, K. W. (1937, December). The dawn of philosophy in music education. Music Educators Journal, p. 24.

A history of the faculty of philosophy of Columbia University. (1957). New York: Columbia University Press.

Katz, M. B. (1971). Class, bureaucracy, and schools. New York: Praeger Publishers.

Lee, W. R. (1982). Education through music: The life and work of Charles Hubert Farnsworth (1859-1947). Unpublished doctoral dissertation, University of Kentucky, Lexington, KY.

Program of the sixteenth meeting. (1923). Music Supervisors National Conference Yearbook 1923, 13-21.

Seashore, C. E. (1913). Editorial: The educational efficiency engineer. Journal of Educational Psychology, 4, 244.

Snedden, D. (1917, July). The waning power of art. The Journal of Sociology, pp. 801-821.

Snedden, D. (1923). The future of musical education in the public schools. Music Supervisors National Conference Yearbook 1923, 45-53. (a)

Snedden, D. (1923, August). Gopher Prarie-A.D. 2000. School and Society, pp. 211-216. (b)

Snedden, D. (1927). What's wrong with American education? Philadelphia: J. B. Lippincott Co.

Snedden, D. (1931). Cultural educations and common sense, a study of some sociological foundations of education designed to refine, increase, and render more functional the personal cultures of men. New York: The Macmillian Company.

Snedden, D. (1934, May). Rough going ahead: Some social faiths and doubts. Teachers College Record, pp. 676-682.

April 26, 1983 